\title{
小学校通学区域の形成過程
}

一一広島市を事例として—

\section{酒川 茂}

I はしがき

II 通学区域研究の視点

(1) 従来の研究

(2) 問題の所在

III 広島市の概要々小学校の立地変化

(1) 市域の概観

（2）小学校の立地変化
（3）通学区域に関する法的規制

NV 広島市に拈将る小学校通学区域の形成 過程

(1) 旧城下町地域

(2) 市街地周辺地域

(3) 新合併地域

\section{I はしがき}

わが国に和ける近代的教育制度は 1872年 (明 治 5 年) に公布された学制に端を発する。初等 教育にあたる小学校は, 後に小学校令 (1886) によって義務教育と明記され，明治時代末年に は就学率が飛躍的に向上するに及び，義務教育 としての体裁を整えた。以来, 名称は尋常小学 校, 国民学校，小学校と変化したが，その実態 は大きく変わることなく, 最も身近な教育施設 としての地域中心たる役割を果たしてきた。

小学校を中心として構成される地域は, 自然 発生的に形成されるものではない。小学校には 通学区域が定められて和り, その区域内に居住 する児童は，原則として指定校以外での就学は できないことになっている。通学区域とは，児 童・生徒の通学上の便宜を考慮して, 彼らの就 学ないし通学区域の調整をはかるために設定さ れた一定の地理的範囲とされる。一般的には学
区とも称されるが，学区は広義には上記の意味 のほかに, 学校々の他の教育施設の設置, 維持 をはじめ，それらの管理，運営などの主体をな す教育行政上の単位という意味をも含んでいる。 学制に和いては，広義の学区が制定されてい た。しかし，この時期は，井户，宮川も述べる ように，学校制度の形成期であり，学校そのも のの形態さえ試行錯誤を重ねていた段階である。 学区は，当時施行された大区小区制とともに形 式地域であり，旧来の地域生活や住民感情との ずれが大きかったといら。また，行政組織とは 全く独立して学校を設立維持してゆくのは, 財 政上無理であった。そのため, 1879年には学制 は廃止され，新たに教育令が公布された。この ときから小学校の設置主体は市町村とされるよ らになった。これは郡区町村編制法 (1878) に よる旧町村の復活に呼応したものである。1 880 年, 教育令が改正されたのに伴なって, 小学区 の設定基準は次のように定められた。すなわち，

\footnotetext{
1）以後論じてゆく小学校は, 公立小学校を指す。

2)『教育学大事典 1 』, 第一法規, 1978, 347-349頁。

3）以後, 学区は広義に和いて, 通学区域は狭義に执いて用いる。

4）井戸庄三「明治地方自治制の成立過程と町村合併」，人文地理21-5，1969，29-53頁。

5）宮川秀一「明治前期に拈ける学区の変遷一とくに兵庫県川辺郡の学区について一」, 地域史研究3-1，1973，1-26頁。

6）井上久雄, 『近代日本教育法の成立』, 風間書房, 1969, 24一26頁。
} 
学区の境界は 1 町村の境界もしくは数町村連合 の境界と合致すること, 小学校を設立, 維持す るに足る資力のあること，叔よび学齢児童の通 学に便利なことである。それい以来, 通学区域は, 広義の学区 (市町村, またはそれらの組合) とは必 ずしも一致しなくなった。

ある通学区域において，長期間にわたって児 童が 1 つの小学校に通学し，さむざまな行事を 共にすることによって，児童ばかりでなく，父 兄や他の住民の間にも関連が生じてゆく。こう した段階を経て, 通学区域は次第に小学校を中 心とする一種の社会領域化してゆくと考兄られ る。渡辺はそれを学校社会地域と呼び, 教育令 以後に形成され始めたとみなしている。とはい え, 通学区域は, その後一定の区域を保ったわ けではなく, 制度上の変化や地域変化に伴なっ て変遷をたどってきた。かかる変遷の過程を分 析することは, 社会領域の形成や变化を, 教育 施設の役割を通して明らかにするらえで非常に 重要である。

小学校は児童が利用する教育施設であるから， 通学区域は通学距離の制約をらけるはずでめる。 その基準は, 戦前には上記の項目を越觉る内容 は示されなかったが, 戦後の学校教育法施行規 則に基づき, 通学距離 $4 \mathrm{~km}$ 以内といら限界值 が示された。ところが，過疎化に伴なら学校統 合の行われた僻地では，この限界值を大きく上 回る広い通学区域をもつ場合が少なくない。一 方, 人口稠密な都市地域では, その通学区域は 市域を細分することになり，非常に狭い。この ように，通学区域の現状は地域によって大きく 異なっている。

筆者は先に，都市地域である広島市旧市域を 事例として, 戦後の小学校通学区域の変化を都
市化との関連に预いて考察した。その際, 同じ 都市地域内であっても，もと城下町であった都 心部と，昭和初期から戦後にかけて合併した周 辺部とでは，小学校の立地や通学区域変化の様 相が異なることが観察された。また，通学区域 が変更される場合，地元住民によってさまざま な意志表示が行われた。そのなかには，もとの 通学区域に帰属していたいとする例ばかりでな く, 地域の変化に応じた新たな通学区域設定を 望む例もあった。いずれにせよ，これは住民が 小学校通学区域を社会領域として重視している ことの例証と考光られる。

それゆ光，本論では，小学校通学区域が一社 会領域であるとの前提のもとに，その通学区域 がいかなる過程を経て形成されてきたかを明ら かにすることを目的とする。そのため，今回の 研究では広島市の全域をとりあげ，地域性の差 異が通学区域の形成にいかに反映するかを考察 する。その際こうした区域の単位になると考 兄られる近隣集団や地縁社会との関連も考慮し てゆく。広島市の行政的な市域には，都市内部 地域とは違った地縁社会をもつ農村地域も含ま れている。例えば，今な沶大字区画の残る地域 や，新しく開発された住宅団地等である。時期 的には明治初期から現在に至る間の変化をとり あげるが，考察の主眼は戦後，1980年までの変 化に沶くことにする。

\section{II 通学区域研究の視点}

(1)従来の研究 具体的な分析に入る前に, 従来行われてきた研究の論点を整理し，問題の 所在を明確にしておきたい。通学区域が多くの 行政区域と一致し，かつ社会領域の一つである ところから，地理学のみならず，教育社会学や

7）千葉正士，『学区制度の研究一国家権力と村落共同体』，勁草書房，1962，169頁。

8）渡辺久雄「学校社会々行政地域一富山県下未合併村を中心とした考察一」，人文研究8-10，1957，61一83頁。

9）横田光雄編著，『公共施設財源便覧一明日の住民福祉のために一』，ぎょらせい，1975，15一-18頁。

10）酒川茂「広島市旧市域に和ける小学校の通学区域と人口变動」, 石田宽教授退官記念事業会編『地域一その文化と自 然』, 福武書店, 1982，256一-263頁。 
法社会学などの分野からの研究も多い。また， 教育行政と深い係わりをもつため，地方行財政 ほか，最近ではュミュニティとの関連からの研 究もみられる。

まず，形式地域の実質地域化といら観点から 通学区域を論じたのは渡辺でするる。彼は，戦後 の町村合併に対して，住民の態度が消極的また は否定的であった理由を，市制・町村制 (1888) によってできた形式地域である当時の市町村が その後実質地域として充分に成熟していたこと に求め，さらに，その過程で明治以来の教育効 果が深く係わったとしている。教育効果とは， 学校での教育だけでなく，家庭や社会教育とい ら学校と密接に結びついた社会 (学校社会) が住 民に及洔す効果をも意味している。これは, 水津 が，「小学区が，『基礎地域』相互の共属意識を つよめ，『基礎地域』の拡大に，実質的な影響 をあた劣た」と述べたことと一致した考え方で ある。義務教育が徹底し，大幅な法的改正のな くなった明治後期から戦後に至るまでが，通学 区域が穾質地域へ変転する時期であったとい兄 よう。その時期に和いて小学校の果たした役割 については，これらの研究でも触れられている が，千葉(注 7) 2頁〕はさらに，「小学校はその 区域たる村落の社会学的な構造・機能を変化さ せる重要な一つの要因である」との見解を明確 に示している。しかし，高校のように通学区域 が広い場合，実質地域となり得ないこともある。 坂口は京都市近郊に和祃る廃村化の現象を考察 し, 戦後の学歴社会の発達のなかで, 京都市近 郊が日常生活とは完全に遊離した大都市地域内
の高校通学区域に帰属していたことが，この地 域の挙家離村を助長する要因になったと述べて いる。そして，この地域に抢ける挙家離村を， 生活圈と通学区域の一致を求める行動であると みなしている。

しかしながら，次第に実質地域に変化してい ったと考兄られる小学校通学地域も, 戦後急激 に変化してゆく。特に農村地域では学校統合が 相次ぎ，通学区域の拡大とともに，地域の中心 である小学校もその性格が変化していった。山 形県に和ける学校統合をとりあげた溝口による と，小学校は山村の閉鎖された生活状況のなか で利用しうる唯一の公共施設であった。また， 西男は，村外からの情報が学校を通じて入って きた面もとりあげ，小学校はコミュニティ・セ ンター，情報センターとしての役割を果たして いた点を強調した。彼は，学区の広域化した新 設統合校には統合前のような小集団的性格はな くなったと述べている。さらに，学校を利用す る住民も, 行政主導の行事（村政相談室, 料理講 習会等）に参加するにとどすっていることから， 学校は共同体的拠点 (Gemeinschaft) から利益集 団的拠点 (Gesellschaft) へ移行したとみなして いる。小規模な分校が本校へ統合され，こうし た共同体的拠点を失った地域について，大橋は 地域の基盤の衰失であると表現している。

かかる変化状況のなかで，さまざまな住民の 対応がみられ，学校統合に伴なら摩擦が多く経 験された。若林は，学校統合をめぐる反対運動 は，統合自体に反対するよりもむしろ，町村合 併経過や学校統合決定に和ける住民無視の非民

11）水津一朗，『社会地理学の基本問題』，大明堂，1980，139頁。

12）坂口慶治「京都市近郊山地に批子廃村化の機構と要因」, 人文地理 $27-6,1975 ， 1$ - 32 頁。

13） 1953年, 町村合併促進法が制定されて市町村の合併が進み，続く新市町村建設促進法（1956）に基づいて，小中学校 の統合が急速に進んだ。

14）溝口謙三「地域の中の学校」, 教育社会学研究27，1972，19-30頁。

15）西田博嘉「山村に拈ける学校の廃校化と廃校施設の転用一奥吉野山地十津川村の学校統合を中心に一」，人文地理262, 1974，89-103頁。

16）大橋幸文「長野県に括ける学校統廃合の推移々課題一1955年以降を中心として一」，日本地理教育学会大会発表要旨 (1981年 8 月 7 日)，1136一-1147頁。

17）若林敬子「学区と村落社会一戦後町村合併期の学校統合問題一」，村落社会学研究 9，1972，255一-302頁。 
主的な地方政治への抵抗に原因があるとみなし ている。稘口，望15)] 述べているように，住民 は学校統合自体にはむしろ関心と期待を抱いて いたのである。若林は，学校統合に関する行政 側の考え方は，町村合併によって生じた新しい 行政圈と住民の生活圈とのギャップを融和し， 地域住民を実質的に国家権力による支配構造に だきこむイデオロギー政策であるといら見解を 示している。しかしながら，学校統合は財政的 理由によるところが大きかったことから，筆者 にはこのようなイデオロギー政策とは考㝋難い。 利益集団的拠点に変質したとしても，地域の 中心である小学校をもつ通学区域はまた，近年 さかんに唱えられるコミュニティ論にとっての 地域的枠組の根拠を与える。コミュニティ運動 は1910年代に合衆国で起こり，その目的は，都 市を分割し，その内部に拈いて公共の施設を媒 介にしながら人間接触を高めることであっだ。 これは，すなわち近隣住区の構築をめざしたも のである。その規模が，1小学校区の人口規模 とされる点について, 渡辺は, 「小学校の運営 上の適正規模から算定されるそのサービス圈の 規模と, 学童の適正徒行限界といら本来相互に 独立の 2 変数の一致の上に成り立っている」と 述べている。わが国でも1970年，自治省がコミ ニニティ構想を発表し，比較的狭い地域に括け る共同意識を基礎とした市民集団を小学校区単 位でまとめ，環境整備を行おらとした。しかし， 小谷も述べるように，「いまだ伝統的地域社会
としての性格が色濃く残る農村地域あるいは都 市化の緩やかに起こっている地方都市では，上 からコミュニティの範域を校区的に編成するこ とは，必ずしも適当であるとは言えない」す なわち, 強固な地域社会が存在する場合には, 便宜的に小学校通学区域をコミュニティの単位 とするべきではないことを意味している。では, 都市地域ではどうかというと，広島市を事例と して行った森川の研究に和いて, 自然発生的な 生活圏である最寄品商圈と，作為的に形成され た生活圏である小中学校区との整合性が非常に そしいことも報告されている。

都市地域に和ける小学校通学区域を考光る場 合，上記のごとく生活圈との整合がそしいとは いえ，この地域には近隣集団である町内会組織 の存在も考慮されるべきである。佐藤は祇内会 について，「コミュニティの形成といら面から の評価はゼ口に等しい」と述べ，秋先，石田も 同様に否定的見方をしている。それに対して中 川は町内会を, 近代的地方自治の枠内では正当 化され難いとしながらも，日本人にとってコミ ュニティは，対面接触の可能な最大限度である 町内会の範囲に行きつくといら見方を示してい る。これは，越智が，「イェ・地区といらフォ ーマルな制度を, 社会機構の要請からくる枠組 として，行政から指示あるいは示唆されたりす ると，日本人は大きな抵抗なしに受け入れる」 と述べているのと同様，きわめて日本人的な特 性に立脚した見解といえよう。島村・鈴鹿も京

18）倉田和四生「大都市とコミュニティ」, 神戸都市問題研究所編『コミュニティ行政の理論と実践』, 勁草書房, 1979, 42 - 57 頁。

19）渡辺俊一「米国近代都市計画に括ける近隣住区論(上)，(下)」，都市問題66-5，6，1975，72-87頁，82一96頁。

20) 自治大学校編『自治用語辞典』, ぎょらせい, 1978, 356頁。

21）小谷朋弘「コミュニティ形成と行政の対応一広島市のコミュニティの現状分析を中心に一」, 都市政策研究 1,1981 , 106一141頁。

22）森川洋「広島市の地域特性一等質地域と結節地域の分析による一」, 都市政策研究 1，1981，55一-105頁。

23）佐藤竺，『コミュニティをめぐる問題事例』，学陽書房，1980，339頁。

24）秋元律郎「都市の政治と地域住民組織の役割」，都市問題70-4，1979，3-15頁。

25）石田頼房「まちづくりと地域住民組織」, 都市問題70-4，1979，16一27頁。

26）中川剛，『町内会』(中公新書591)，中央公論社，1980，210頁。

27）越智昇「町内会の組織分析」，蓮見音彦・奥田道大編『地域社会論』，有斐閣，1980，335一-366頁。

28）島村昇・鈴鹿幸雄，『京の町家』，鹿島出版会，1971，235頁。 
都市に特ける強固な町内会組織を示し，「京都 の町内は維新後全国に先がけて創設された学区 制によって統括され, 町内より1ランク上の地 域, 学校区が設定された」としている。町内会 組織は全国の都市地域に存在して括り, 京都市 以外の都市に执いても, 小学校通学区域との関 連があると考えられる。

通学区域の変化を具体的に扱った研究には戸 祭のものがある。彼は堺市を事例として明治初 期以来の小学校通学区域の变遷を論じ, 地域に よって通学区域の特徴が異なることを指摘した。 明治時代は教育制度叔よび地方自治制度自体の 確立期であるため, 制度の変化に伴なって改変 される通学区域と行政区画との関連が論述の中 心である。そのなかで, 通学区域境界としての 主要道路や鉄道線路, 旧村境界の役割, さらに 通学区域厳守といら最近の傾向などに触れて特 り, 通学区域形成の要因をいくつか知ることが できる。しかしながら，彼も指摘しているよら に, 都市化と通学区域変化との関連, 区域変更 時の関係当局の配慮, 住民の反応という点をさ らに考慮することが必要であろう。

以上のように, 通学区域研究の論点を整理し てきたが，これらの研究から考えられる問題の 所在を次に述べてみたい。

(2)問題の所在 上述のごとく, 小学校通学 区域を対象とする研究の多くは，学校統合とそ れに伴なら通学区域変更に対する住民の対応に 関するものであった。他は，行政区域などの 形式地域が実質地域に变化してゆく過程で, 通 学区域の果たした役割を考察するか，あるいは コミュニティ設定に和ける地域的枠組として, 通学区域の是非を論じたものであった。すなわ ら，小学校通学区域が地域住民の生活に重大な 影響を与えてきたことは充分に認識されていな がら，年祭2 麦除いて，学校統合時に通学区域の
変化が問題として顕在化するまで，正面からと りあげられることがなかったのである。

しかしながら, 通学区域は学校統合による以 外にも，地域の変化に応じて改変が加えられる ものである。それゆ光, 小学校通学区域の形成 過程を明らかにするためには，長期間にわたっ て, 地域の変化とともに通学区域の変化を考察 してゆかなければならない。㴶29)る研究に挨い ては，明治期に重点を和いて考察が進められて いるが，住民の意志が教育に反映できるように なった戦後の時期をより重点的に検討すべきで あろう。また，地域の変化を明確に把えるため には，彼と同様，性格の異なる地域を同時に考 察するべきである。

次いで，彼の研究ではほとんど触れられてい ないが，通学区域形成を地縁社会との関連に拉 いて考察してゆくために，行政区域や大字との 関連はもちろんのこと, 都市内部地域では特に 近隣集団 (町内会・自治会) との関連をも考慮す る必要がある。これらの近隣集団は, 前述のご とく現代に括ける存在意義が疑問視されている とはいえ, 地縁社会が成立しにくい都市地域に あって地区的にまとまり，住民の意志を行政側 に示す組織であることにらがいないからである。

以上のような留意点に基づき，以下に具体的 な分析を行ってゆく。通学区域の変遷について は資料調査のほか，変更当時の教育委員会担当 者や小学校長などへの聴き取り調査を併用した。 また，地縁社会との関連については，主として 現地での聴き取り調査から考察した。

\section{III 広島市の概要と小学校の立地変化}

(1)市域の概観 現在の広島市域は，もとの 広島城下の地域が1889年に広島市となって以来, いくたびかの周辺町村の合併によって形成され たものである。合併町村の位置，合併年，和よ

29）戸祭由美夫「堺市に乱ける通学区域の変遷」，人文地理28-4，1976，27一65頁。 
び町村内大字は第1 1 図に示すと㧸りである。広活発化するなかで，1929年に 7 町村が広島市 島城下の周辺に位置していた町村は, 安芸郡仁 に編入された。また，戦後の町村合併促進法 保島村字宇品が1904年に広島市に編入されたの （1953）に基づいて，さらに 2 村が広島市に編入 をはじめ，都市計画法 (1919) に伴なって，全 されている。これらの町村は，それぞれ農村・ 国的に大都市への周辺町村の編入合併の動きが

漁村といらょうに性格を異にしていたが，もと
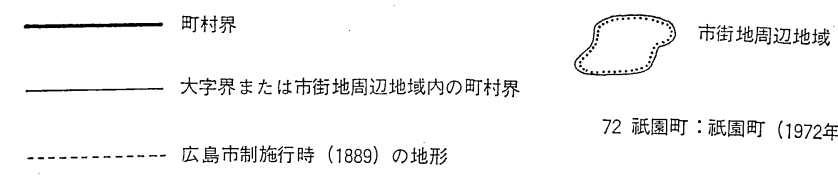

72 祇園町：祇園町（1972年会併）

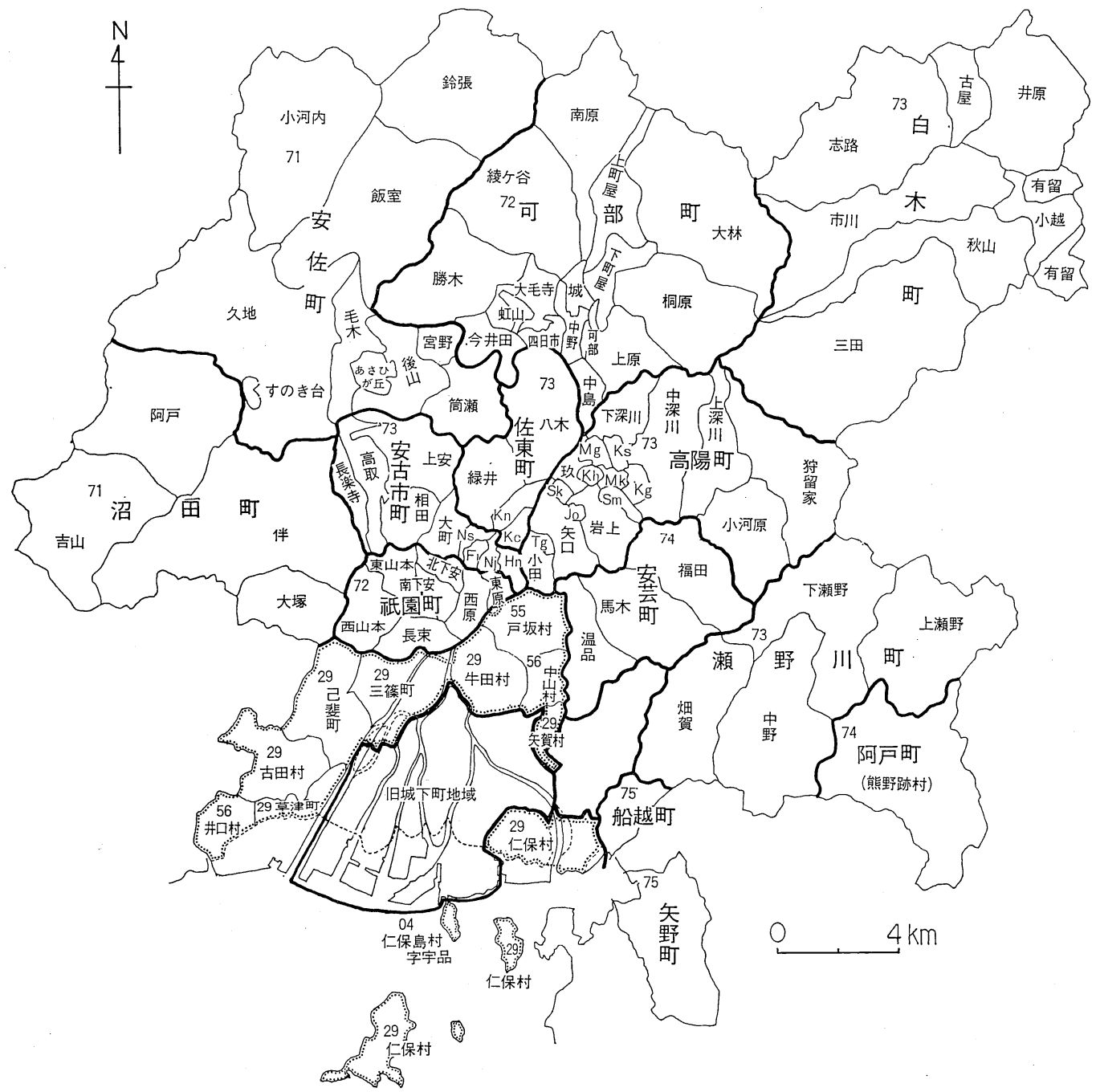

第1図広島市域内の区分, 合併町村名・合併年就よび町村内大字区画

安古市町 $\mathrm{Ns}$ : 中須 $\mathrm{Fi}$ : 古市 $\mathrm{Nj}$ : 中筋 $\mathrm{Hn}$ : 東野

佐 東町 $\mathrm{Kn}$ : 川内温井 $\mathrm{Kc}$ : 川内中調子

高陽町 $\mathrm{Ks}$ ：亀崎 $\mathrm{Mg}$ : 真亀 $\mathrm{Kh}$ : 金平 $\mathrm{Mk}$ : 諸木 $\mathrm{Kg}$ : 倉掛 $\mathrm{Sm}$ : 末光 $\mathrm{Sk}$.翠光台 Jo:城ヶ丘

30）広島県編『広島県史』地誌編，1977，716頁。 
もと藩土や武家奉公人も多く，広島城下の地域 と密接な関係を有していた。しかし，その後 1965年頃から具体化され始めた広島広域都市圈 の開発構想に沿って，1971～75年に広島市に編 入された町村は，上記の町村注どの緊密さはみ られなかった。

戦後合併した町村の人口推移は第 2 図に示す ごとくになる。人口の増加は初め，もと広島城 下の地域に和いて顕著であったが，次第に周辺 の町村に及び，現在の人口増加の大半は1971年 以後の合併町村に移っている。戦後のベビーブ 一ム期に和ける人口増加は，主にもと広島城下 の地域に存在した旧軍用地または農地が住宅地

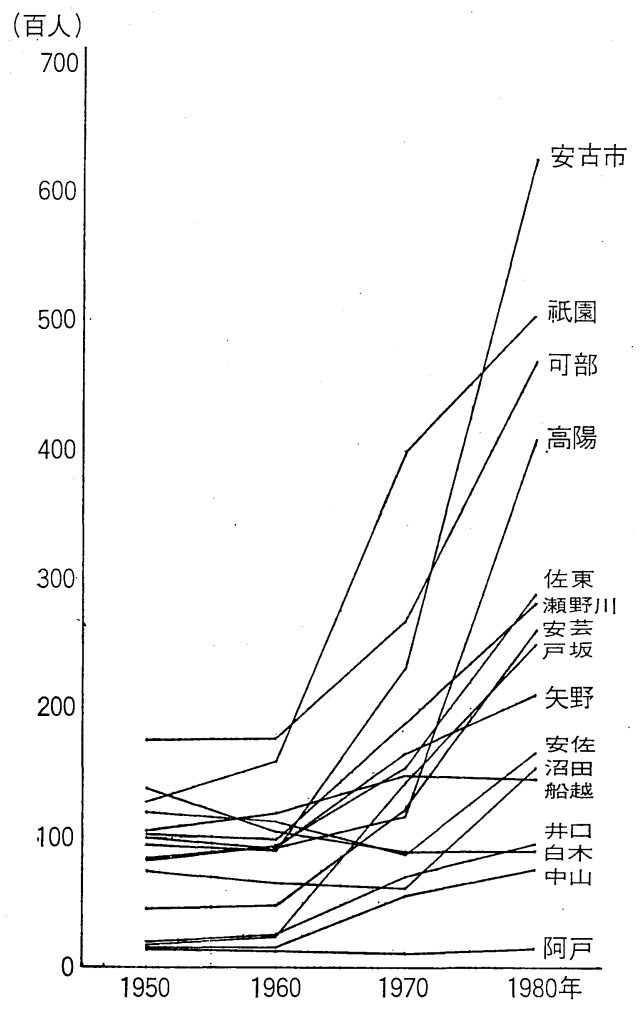

第 2 図 戦後合併町村における人口変動

（資料：国勢調查）
に転用されたことによる。その後，1960年頃よ りドーナッ化現象が現われ，宅地化は周辺部へ 進展していった。特に, 安古市町, 高陽町に代 表される大規模住宅団地の開発は，地域の様相 を農村から住宅地へ急速に変化させた。

一方では, 安佐町, 沼田町, 白木町のように 人口が減少していった町もある。安佐町や沼田 町のように近年急速に宅地開発が進んだ地域は, 人口が増加に転じてはいるが，同じ町域内でも 住宅団地のある人口稠密地区と，それ以外の人 口稀薄地区が混在している。白木町は近年やや 人口が境加したとはい光，未だに農村的性格の 強く残る地域である。人口移動によって住民の 構成は各地で変化しているが，最近の産業人口 構成は第 3 図に示すごとくである。人口流出の 続いていた都市部で，最近若干の人口増加が認 められる地区がある。これは gentrification と 呼ばれるもので，宅地開発があまりにも遠方に 拡がり，都市部への通勤に要する時間的・経済

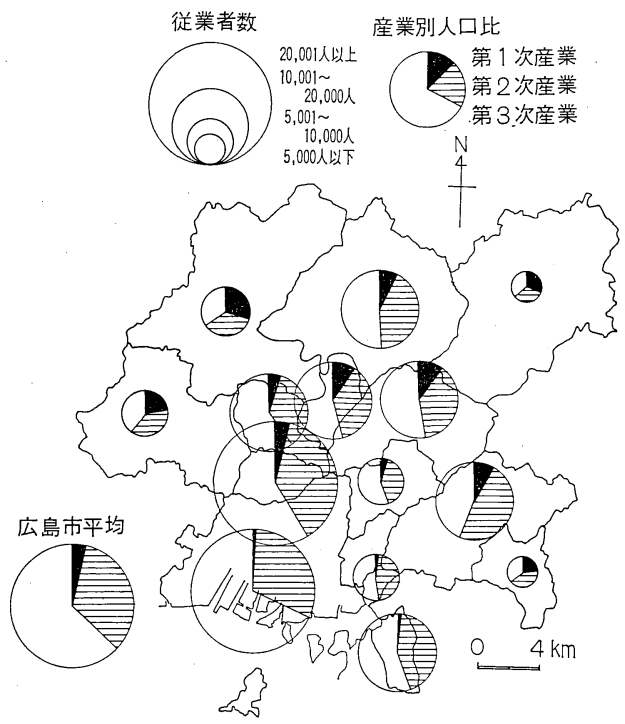

第3 図広島市に和ける各町の産業別人口比 旧城下町地域と市街地周辺地域は一括 （資料：昭和50年国勎調査）

31）広島市編『新修広島市史』第 4 巻・文化風俗史編，1958，327貢。

32）広島市編『高陽町史』，1979，522頁。

33）山口岳志 「Gentrification 考」, 東京大学教荃学部人文科学科, 人文地理学研究室編, 人文科学科紀要 73 , 人文地理学 $V I$, 1981，41一52頁。 
的負担増加に見切りをつけた住民が，都市部に 増加したマンションへ移転したことが原因の一 つとみてよいであろら。

上記のごとく，都市部への距離や関係の緊密 さ，人口変動等によって，広島市は次の 3 地域 に分告しらる。すなわち，旧来の市街地である 旧城下町地域と，戦前から1956年にかけて合併 した市街地周辺地域，和よび1971年以降合併し
たいわゆる新合併地域である。

(2)小学校の立地変化 これらの地域に抹い て，小学校はどのように設置されてきたのであ ろらか。明治初期からの設立統廃合の情況を図 示して考觉てみよう。

第 4 図は，旧城下町地域と市街地周辺地域に 特ける小学校の設立統廃合の状況を示したもの である。まず，旧城下町地域では，1873年広島

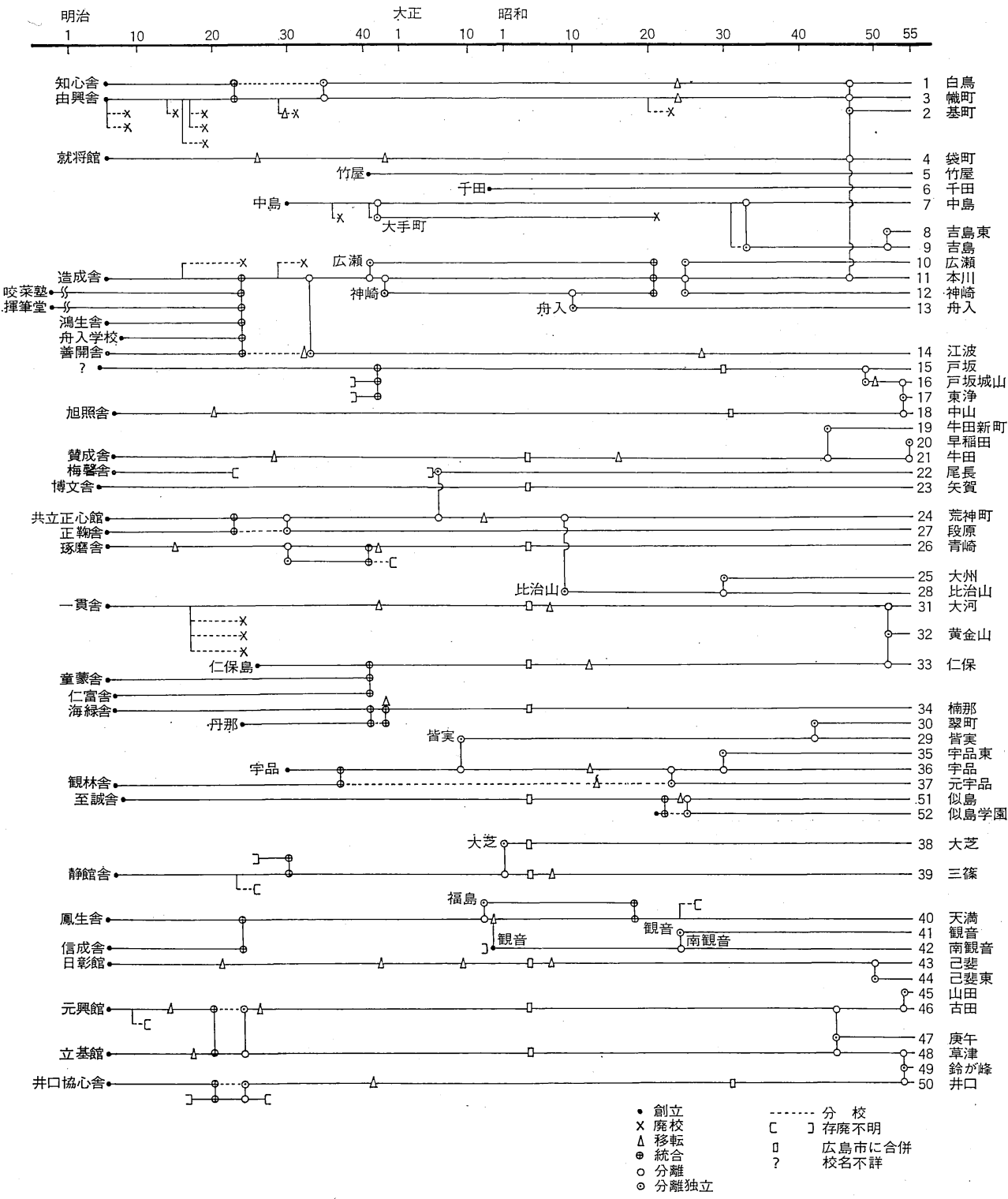

第4 図 旧城下町地域および市街地周辺地域における小学校の設立と統廃合 (䄄中静観館含は 
県令により布告が出され，各小区に 1 校ずつの 小学義校を建設し, 従来自宅で教授していた者 はその生徒をつれて付近配置の義校で教授する ことになった。これらの義校は潘とんど寺社に 扣いて設立され, 内容も従来の私塾・寺小屋と 変わらないるのであったが，この地域に打ける 最初の小学校立地とみなすことができる。翌 1874年以降も, 小学校の設立や分校の設置が頻 繁に行われていった。ただし，分校は既存の小 学校を別の小学校の分校とした場合を除いて, 10年内外で—例外的に, 短いものは 1 年で 一廃止されている。このように頻繁な設立統 廃合が行われたのは，この時期が近代的教育制 度の形成期にあたるためであろう。というのも， 第 4 図から，第二次小学校令 (1890) 和よび第 三次小学校令 (1907) といった教育制度改正の 時期にこれらの設立統廃合が集中しているとみ なせるからである。第三次小学校令によって尋 常小学校は 6 年制になり, その頃から就学率も $100 \%$ に近ついて，近代的教育制度はほほ確立 された。その後は人口増加に応じて小学校が増 設されていった。

1929年に至って, 市街地周辺地域の 7 町村が 広島市に合併した。この地域では当時, 小学校 の増設はみられず, 戦前に和ける小学校の配置 がほ涪確立した1935年頃に設立されたのはすべ て旧城下町地域の小学校であった。
これらの小学校は, 戦争末期には集団柾開や 市内各所での分散授業が行われ，教育体制は混 乱した。ささらに，1945年には原爆被災によって 旧城下町地域, 特に中心部の小学校は, 壊隇的 打撃を受け，一部破壊でやや使用可能な小学校 は11校になっだ。大手町小学校の場合, 児童も ほとんど集まらず，復旧されないまま1946年廃 校された[注39) 96頁】。同年, 広瀬小学校 (10： 学校番号) ・神崎小学校 (12) 坚童は, 本川小学 校 (11) で授業が行われることになり，1950年 に両校が復旧されるまで続いた。これらの小学 校の位置は第 5 図に示すと和りである。被药後 の復旧は続けられ，校舎の整備とともに校具 備品類も充実してきたのは1950年頃とされてい る。

しかしながら，この時期には戦後ベビーブー ム期に出生した児童が学齢に達し, 旧城下町地 域の各小学校は児童数のピークを迎えた。広島 市教育委員会 (以下, 市教委と略記する) の方 針 では，1校の児童数が 1,500 人を越光た場合， 小学校新設を行うのが原則である。とはい光， 中心部では学校建設用地がないため新設ができ ず, 教室の増築と 1 教室 50 人以上のスシ詰め教 室によって児童増加への対処がなされた。袋町 (4)・幟町 (3) 小学校がその典型例であり, 1 校あたり 2,000 人をはるかに越㝋る児童が収容 されていた。

34） 1872 年，大区小区制が公布され，それに基づいて広島城下は第 1 大区となり，12小区に細分された。

35）広島市編『広島市史』第 4 巻，1922（1972年復刻版），277頁。

36）広島県編『広島県史』近代 $1 ， 1980 ， 528$ 頁。

37）広島県教育委員会編『広島県教育八十年誌』, 1954, 資料編 174 頁, 飞上ると, 広島県に扣兴学校への就学率は, 1906年には $99.34 \%$ に達した。

38）広島市教育委員会編『広島市教育委員会の歩み』，1979，220頁，によると，1935年時点での広島市の小学校は 38 校 （分校 1 を含む）であった。

39）広島市編『広島原爆戦災誌』第 4 巻，第 2 編・各説，1971，77，107，109頁。

40）前掲31）639頁による。しかし, 『広島市勢要覽』昭和21年版, 1947, によると, 当時の授業可能校は19校とされてい る。

41）以下，小学校には，広瀬小学校（10）のように学校番号を付す。これは第 4 ～7図に示した学校番号に対応するもの である。

42）前掲31）646頁による。しふし，『広島市勢要覧』昭33和年版，1959，によると，学校施設面での復旧は1958年頃とさ れている。

43）市教委での聴き取りによる。

44）児童数のピークは袋町小学校で 2,368 人（1956年），幟町小学校で 2,505 人（1959年）であった。 


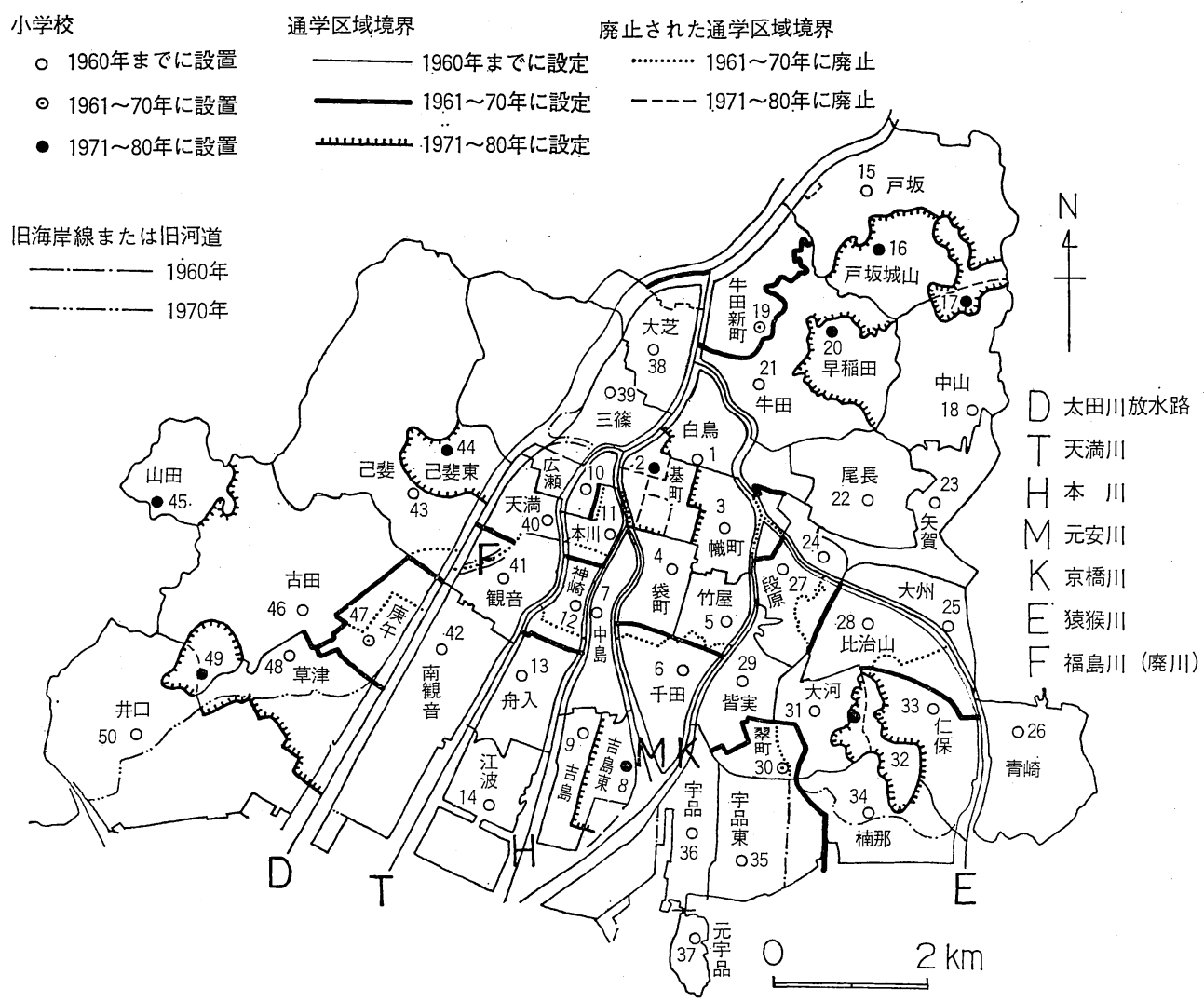

第 5 図 旧城下町地域および市街地周辺地域におけ打る小学校通学区域の変化

(17: 東浄, $24:$ 荒神町, $32:$ 黄金山, $49:$ 鈴が峰)

番号は第 4 図に示す学校番号に対応する。ただし, 51 : 似島, 52 : 似島学園は第 7 図に記載。

1958年の児童数ピークを過ぎてから，今度は 一転して都心部のドーナツ化現象が起こった。 児童数の増加は, まず旧城下町地域の周辺部で 起こり，続いて市街地周辺地域に移っていった。 これらの地域では, 現在に至るまで葟隔年の ペースで小学校新設が行われるようになった。 1972年に都心部に新設された基町小学校 (2) は，戦後不良住宅地（原爆スラム）になっていた 地区が，再開発によって高層住宅街化された時 にあわせて建設されたもので，例外的なもので ある。むしろ, 本川 (11) ・広瀬 (10)・袋町 (4) 小学校のように, 人口流出によって児童数が激
減し，廃校化が検討された例さえある。これら の小学校では当時多くの教室が余っていた。そ こで学校統合を行い, 跡地を公共用地として利 用することが検討されたが，市教委や地元など の反対が多く，実現しなかった。

次に, 新合併地域について同様に小学校の設 立統廃合の状況を示すと，第 6 図のようになる。 明治後期には小学校の立地はほぼ確立したとみ られるが，上述の地域と比べて，新合併地域に は戦後の統廃合が多く, 新設校の多くはごく最 近のものである。

この地域では戦後人口流出が続き, 過疎地域

45）この地区はもと軍用地（西練兵場）であった。

46）広島市議会『昭和48年度予算委員会会議録』，文教関係 (3 月15日), 822頁, による。 


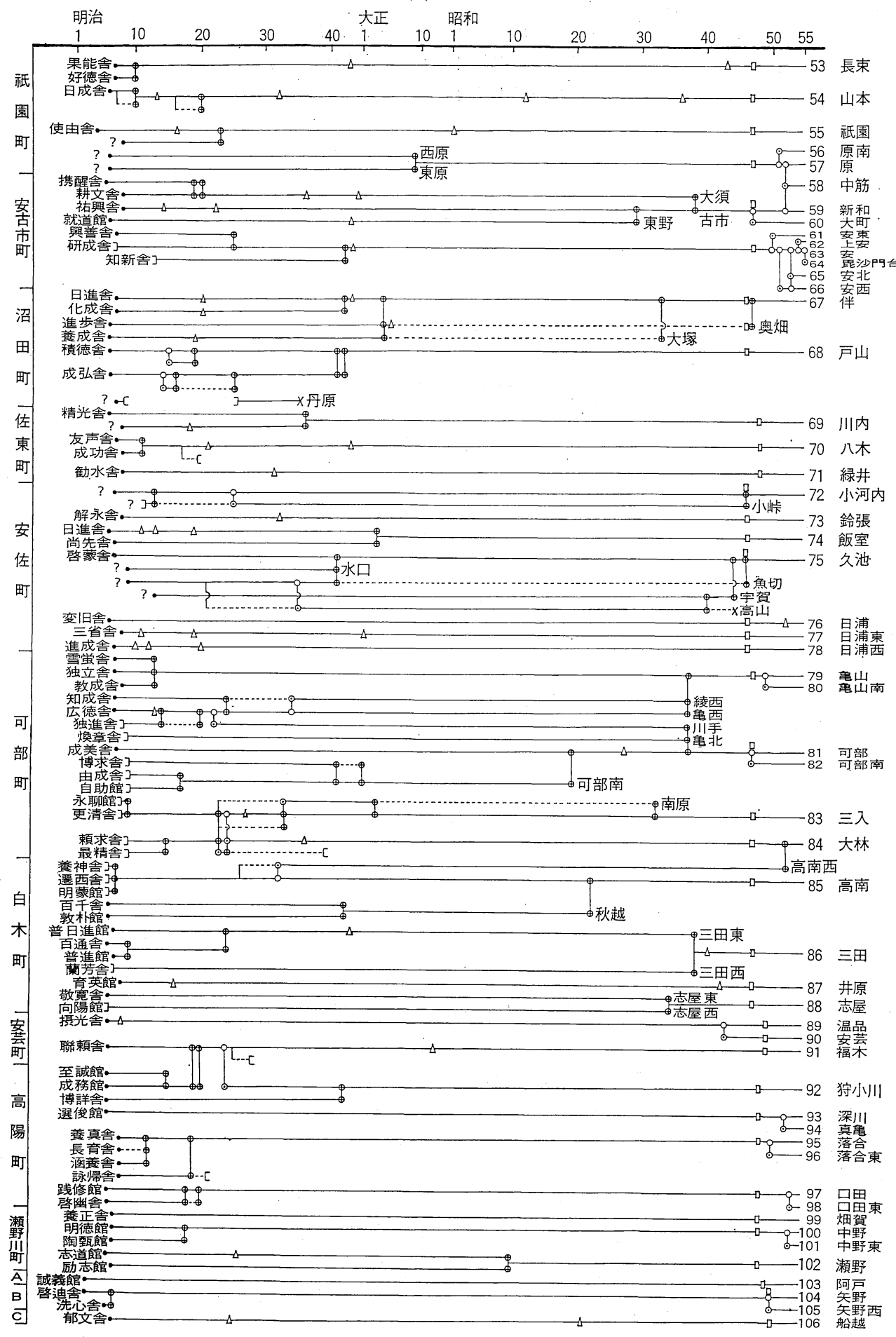

第6 図 新合併地域における小学校の設立と統合

$\mathrm{A}:$ 阿戸町, B 矢野町, $\mathrm{C}:$ 船越町 (凡例は第 4 図江同じ)

船越町は明治初期に海田市町と密接な関係を有していたが，本図では省略した。 
に指定された地区も多いため，適正規模化の方 やや遅れて1971年に統合を終えている。しかし， 向で多くの統廃合が行われた。特に，可部町， その後広島市のベッドタウンとして，これらの 安佐町，白木町で統廃合が多くみられた。可部 町では1962年, 白木町では1963年, 安佐町では 町域の一部で宅地開発が進み, 可部町で 2 校, 小学校 通学区域境界

○1960年までに設置

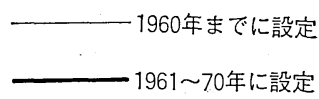

廃止された通学区域境界

○1961 70年に設置

……1971 80年に設定

○1971 80年に設置 安佐町で 1 校の小学校が設置された。また，安

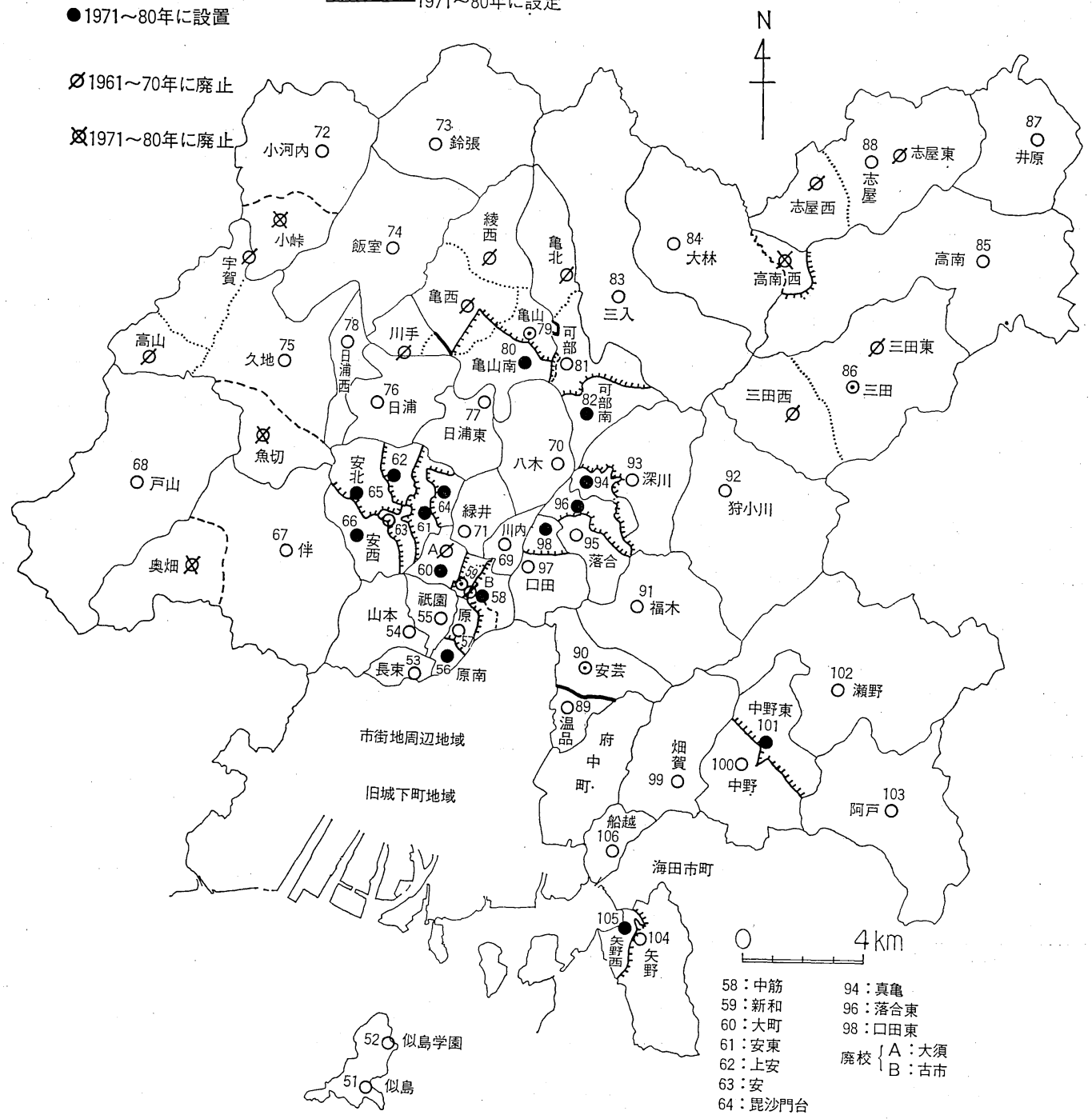

第 7 図 新合併地域における小学校通学区域の変化

番号は第 6 図に示す学校番号に対応する。ただし，廃止された小学校は校名のみ記入した。

47） 公立義務教育諸学校の学級編成及び教職員定数の標準に関する法律（1958）に执いて, 小学校規模の標準は 1 学級 45 人，1学校12〜18学級とされている。

48）安佐町の宇賀小学校高山分校の場合には，入学児童が全く無くなったことにより，廃校された。 
佐町の日浦小学校のように, 大規模 住宅団地 (あさひが丘)の開発に伴ない，団地内へ移転新 築された例もある。これらの変化は第 7 図に示 すと和りである。

近年, 最も多くの小学校が新設されたのは安 古市町と高陽町である。祇園町も新設数こそ少 ないが，各校とも規模が拡大されている。各町 は人口増加に応じて校舎増設を進め, 一部で新 設も行われたが，本格的な小学校新設は広島市 への合併後, 合併計画に伴なら建設計画に基づ いて進められた。しかし，地価の急騰によって 用地取得さ元困難であった。年ここで，市教委は 児童数の予測をもとに，事前に広島市開発公社 または住宅公団, 住宅供給公社に教室または小 学校の建設を先行させ, 後に市が買取ってゆく 方法をとるようになった。それでもな和教室不 足は続き, 現在でも小学校の新設が必要とされ ている。ただし，これらの地域のなかでも高陽 町に和祃る住宅団地では, 学校などの公共施設 の整備は建設計画に最初から組み込まれており, 他のスプロール的開発地域とは異なる立地過程 を経ている。そして，1982年には 4 居住区の各 々に小学校の新設が完了した。

統廃合や新設の目立つ地区とは違って, 小学 校の立地が汇とんど変化しなかった地区もある。 町域の狭い船越町の船越小学校 (106), 阿户町 の阿戸小学校 (103) の注か, 瀬野川町の瀬野 (102) - 畑賀 (99) 小学校, 安芸町の福木小学校 (91), 高陽町の狩小川小学校 (92), 安佐町の鈴
張 (73) ・ 日浦東 (77) ・ 日浦西 (78) 小学校, 沼 田町の戸山小学校 (68) の各地区がその例であ る。これらの小学校は, 宅地化の進んでいる地 区に立地しているものもあるが，特に山間部の 小学校は，人口の減少しつつある旧来の農村的 性格の色濃い地区に立地している。

(3)通学区域に関する法的規制 小学校の立 地については上記のような変遷をたどってきた が，それに伴なって通学区域はどのように变化 してきたのであろらか。ここで通学区域に関す る法的規制について若干触机たうえで，次章か らの具体例による考察を行いたい。

前述のごとく，1873年の広島県令による布告 は広島市に括ける最初の小学校設置を指示した ものであるが，同時に，通学区域設定の最初の 例とみなすことができる。この時期は小学校の 設置主体としての学区がそのまま通学区域であ った。その後, 1883年, 学齢児童就学督責規則 が実施されてから，小学校の設置主体は広島区 となった。すなわち，学区（小学校の設置主体） と通学区域は異なる状態が現在まで続いている のである。1890年には地方学事通則, 1892年に は学齢児童就学規則が定められ，小学校の義務 教育化が進んだ。しかしながら，通学区域は現 在のように厳格に設定されたものではなかった よらである。その後, 小学校の設置に伴なって 通学区域は改変されていったが，区域設定に関 して明瞭な基準は定められなかった。いわば慣 例に従って通学区域が設定されていた。

49）例えば，広島市・安古市町合併協議会『広島市・安古市町合併建設計画書』，1973，23一25頁，飞招いて，児童急増 に対応するため，小学校の新設 2 校，増築 2 校，概算事業費 27 億 5 千万円が見込まれている。他の新合併地域の町村に ついて, 同様の合併建設計画で小学校新設が見込まれているのは, 祇園町, 佐東町, 高陽町, 可部町, 瀬野川町である。

50）祇園町編『祇園町誌』，1970，283頁，によると，祇園町ではすでに1960年頃から地価の上昇によって，移転新築用地 の確保に苦慮していた。

51）国庫負担法の特例事項により，翌年の 9 月までに一度に 300 戸以上の団地，住宅が建設される見込みのある場合，学 校新設の補助を一年先行して出すというものである。

52） 1969年，広島県が合計 1 万戸の住宅団地の計画を立て，1972年より広島県住宅供給公社が建設にとりかかったもので ある。

53） 1878年より，第 1 大区は広島区となった。広島区はこの後，市制・町村制によって広島市となり，以後は広島市が小 学校の設置主体となっている。

54）広島市立中島小学校編『創立七十周年祝賀記念誌』，1967，によると，「明治17，8年頃，本校（の前身）は袋町小学 校に合併吸収されたようである。明治30年の本校創立までは学区もはっきりせず，独立していなかったらしい」とある。 
1960年に至り，市教委は『広島市立小学校及 び中学校通学区域に関する規則』を制定した。 これは, 戦後, 市内中心部の有名校へ正当な理 由なく区域外就学 (いわゆるモグリ入学)する者 が増えたことに対処するための措置である。同 規則をもとに厳しく通学校の指定衔告が行われ， この種の区域外就学は次第に沈静化していった。 しかし, 新たに問題が生じてくる。当時, 戦災 復與事業による区画整理が進展し，それに伴な って新住居表示が実施され始めた。そのため， 旧来の区画・町名に基づいていた通学区域を地 域の変化に対応させる必要が生じた。新住居表 示実施と同年 (1965), 広島市立学校通学区域審 議会が設けられ，検討が始まった。同審議会規 則によると，新町界町名に準拠するだけでなく， 通学時の交通安全, 学校の適正規模の維持, 地 域感情なども考慮することが規定されている。 高学年の児童は卒業まで従来ど和りの小学校へ 通学することが許可されるなど，過渡期として 柔軟な措置もとられたが, 以後, 通学区域は厳 守の方向をたどる。同審議会は現在でも活動を 続けて和り, 小学校新設に伴なら通学区域設定 ほかの小修正にあたって，市教委に修正案を答 申する形をとっている。

\section{IV 広島市における小学校通学区域の形成過程}

以上の考察から，広島市は地理的性格の異な る 3 地域, すなわち, 旧城下町地域, 市街地周 辺地域，新合併地域に分かれて和り，小学校の 立地にもとれが反映していることが明らかにな った。本章では，これらの3 地域についてそれ ぞれ通学区域の変化の様相を把光, 変化に関連 した要因を考察することにより, 小学校通学区
域の形成過程を分析してゆきたい。

（1）旧城下町地域 旧城下町地域に执いて， 小学校通学区域は明治初期〜後期, 明治後期〜 終戦, 終戦〜区画整理期, 区画整理期〜現在の 4 時期を経て形成されてきたと考觉られる。

最初の明治初期〜後期の時期は，前述のごと く教育制度自体が形成期にあって, 通学区域は 大きな意味をもたなかった時期である。第 1 大 区中の各小区がそのまま小学区とされたのであ るが，5，8番小学義校はとれぞれ第 $4 ， 7$ 小 区に和かれるといら状態であった。また，分校 の設置や統合が頻繁に行われ, 児童は教師に従 って, もとの寺小屋等から新しい小学校に入学 したか，あるいはそれぞれ付近の小学校に通学 したようである。小学区は形式的に設定された が，そのもとになった小区の分割には各小区の 地域的特徵が関与したものであろう。第 $1 \sim 3$ 区には武家屋敷が多く，第 $5 ， 6$ 小区 (ともに 北半部)には町屋敷が多かった。第 4 小区は武 家屋敷・町屋敷・寺院が混在して和り, 第 7 12小区は新開または近郊農村であっだ。しかし， 地縁社会の一つである氏子圈との関連について は，第 2 小区が碇神社の氏子圈と一致している のみであった〔注31)，337頁〕。

次に義務教育制度が確立した明治後期〜終戦 の時期に和いて，通学区域は厳密なものではな いにせよ，定着していったと考えられる。人口 増加に応じて小学校は増設されたが，もとより 強固な地縁社会が存在しなかったため, 通学区 域の設定にあたって，地縁的な要因は関連せず, もっぱら人口分布に従って, 通学区域境界には 明瞭な地物が多く用いられた。例えば，1911年 に設置された大手町尋常小学校と，母体校であ

55）越境入学とも言われるが, 学校教育法施行令第 9 条において, 合法的な区域外就学にも越境入学の語が用いられてい るので，ここでは，モグリ入学の語を使うことにする。

56）広島市立本川小学校編『創立百周年記念誌』１973，のなかに，本校の前身である造成舎に対して創立当初，「習字を 教支ていた田川俊之助といら人, 善応寺の左涱禅祐といら人，(中略）の諸氏も弟子をつれて，この学校に合併した」 との記述がある。

57）広島市編『新修広島市史』第 2 巻・政治史編，1958，442一 444頁，第 3 巻・社会経済史編，1959，103一112頁，招上 び第 5 巻別怢・地図, とよる。 
る中島尋常小学校 (7) との通学区域境界は元 安川とされた。また，天満 (40)・観音 (41) 尋 常小学校間の通学区域境界は市内電車併用軌道 であり，江波 (14)，宇品 (36) の両尋常小学校 は新開の地域がそのまま通学区域になってい る。

こうして設定されていった通学区域は, 終戦 後大きな変化の時期を迎える。まず，多くの軍 用地が住宅地に転用されたことにより，それら の地区で新たに通学区域が設定された。例えば， もと東練兵場の跡地は, 白島 (1) - 尾長 (22) ・ 荒神町 (24) の各小学校, もと西練兵場の跡地 は, 白島 (1) ・ 嬂町 (3) ・ 袋町 (4) ・ 本川 (11) の各小学校の通学区域に分割された。これらの 地区は急激な人口増加をみたので，各小学校の 児童収容能力に応じて通学区域が設定されたよ らである。また，この時期には 4 つの小学校が 設置されたが，それらはいずれも用地確保の 可能な地区に限られている。中心部では廃校と なった大手町小学校の通学区域が, 袋町小学校 （4）の通学区域に 編入された。この場合, 戦 後，児童がほとんど復校しなかったために，袋 町小学校への編入が可能になったと考党ら”れ る。

その後, 戦災復興事業や太田川改修事業が進 み，区画整理・新住居表示が実施されるように なる。この区画整理期から現在に至る時期は街 区形態が大幅に変化し，従来の通学区域が，更 新された地域の実態に合わなくなったことに対 する修正の時期とみなすことができる。それは、 平和大通りなど幹線道路の建設によって，従来 の社会領域が分断され，さらに通学時の交通の 安全性が問われるよらになったからである。例 えば，京橋川と猿猴川の分岐点にある京橋町地 区では，従来同じデルタ内にある段原小学校
（27）の通学区域に含まれていた。ところが，市 道駅前・吉島線（現・駅前通り）が開通したこと により，道路以南の地区とは分離され，同小学 校への通学も危険になったことを理由に，京橋 町地区の 2 町内会から, 幟町小学校 (3) の通 学区域に変更の要望が出された。第 5 図に示し た限りでは，京橋町地区は京橋川によって幟町 小学校側の地区と隔たっているょうに見えるが， 両地区は 3 つ橋によって密接に結びついて抒 り, この要望は認められ, 通学区域の変更が行 われた。

幹線道路の出現は通学上危険であると考兄ら れるが，当該地区の住民から，異なる意見が出 されたこともある。1952年より建設された平和 大通りの北側に位置する土橋町・小網町はとも に大通り南側の神崎小学校 (12) の通学区域で あった。市教委は両町を本川小学校 (11) の通 学区域に変更する案を示し，土橋町町内会は市 教委案を支持したが，小網町町内会は，町内の 小道よりむしろ安全との反対陳情を行った。位 置的にほぼ同様の立場にある両町が別の見解を 示したことになるが，通学時の交通の安全性が 考慮されたという点では一致している。

このほかに，太田川改修事業によって，1963 年福島川が埋立てられ，天満 (40)・観音 (41) 両小学校間の通学区域境界が变更された。また, 他の地区でも区画整理に合わせた通学区域の変 更が行われたが，いずれも人口稠密な都市内部 地域で, 各小学校とも通学区域が狭いため, 通 学距離は（地元住民による通学区域変更要望の理由 に加えられることはあっても) 通学区域設定に係 わった主な要因とは考兄られない。また，町内 会・自治会などの近隣集団は，通学区域設定時 に市教委と地元住民の意志を交換する機能を果 たしてきたが，その範囲が通学区域設定時に考

58）当時の袋町小学校長, 石田義夫氏によると, 西練兵場あとのいわゆる原爆スラムでは, 南北の大通りによって通学区 域が分割された。

59） 1965 年より 3 年を要して通学区域は全面的に修正された。

60）広島市教育委員会『昭和 40 年度通学区域審議会一件』による。 
慮されることはなぐ，現に 1 町内会を分断する 通学区域境界も存在している。それゆ穴, 旧城 下町地域に和いて，通学区域設定にあたって最 も重要な要因と考えられるのは通学時の交通の 安全性であった。

（2）市街地周辺地域 市街地周辺地域に和け る小学校通学区域の形成時期は, 明治初期〜後 期，明治後期〜合併期（特に1955年頃），合併期 〜現在の 3 時期に分けることができる。

明治初期〜後期の時期は旧城下町地域と同様, 教育制度の形成期であり, 小学校の内容や立地 は頻繁に変更されていた。通常各村に 1 小学校 が立地し，村域がそのまま通学区域をなしてい た。村内に複数の小学校が立地した三篠村や仁 保村に扔いても，市制・町村制による合併でこ れらの村が成立する以前の各村に設置された小 学校がそのまま残ったのである。このうち仁保 村では明治後期に至り, 統合が行われて 1 小学 校となっている。

次に, 明治後期〜合併期に和いて, 三篠町以 外の村では, 村あたり 1 小学校の状態が続き, 村域が通学区域をなしていた。それゆ各，各村 は小学校を中心とする強固な社会領域でもあっ たと考觉られる。牛田村でも同様であったが, 1934年, 牛田尋常小学校 (21) が校地狭险で拡 張もできないとの理由で現在地に移転した。そ の際，もとの新山村 (現・牛田新町地区) の住民 から, 新校地に通学するのは遠くて不便だと反 対の声があがったが，他の場所に用地を確保す ることが難しく, 同地区からやや遠い現在地が 選択された。同地区住民は移転の場所に反対し ながらも, 牛田村が 1 つの学区であり, 通学区 域でもあることには異論はなかったよらである。
合併期〜現在の時期に至ると, 市街地周辺地 域は人口が増加し, 広島市近郊の農漁村から, 旧城下町地域と一体化した住宅地に変貌した。 それによって，もとの行政区域境界は通学区域 境界としての意味を汪とんど失い，かわって， 旧城下町地域と同様, 通学時の交通の安全性が 通学区域設定に大きな意味をもつようになった と考光られる。已斐 (43) - 古田 (46) 両小学校 間の通学区域境界が, 1960年, 新しい国道 2 号 線に变更されたのはその例である。しかし，三 篠 (39) - 広瀬 (10) 小学校の通学区域境界のよ うに，市街地として一体化しながら，もとの行 政区域境界が通学区域境界として残される例も あった。もと福島川によって隔てられながら, 三篠町に含まれていた地区 (現・中広町三丁目) 住民は, 広島市内の小学校通学区域の全面修正 が行われていた時, 従来ど括り三篠小学校への 通学を希望し, 承認されている。この地区は三 篠神社の氏子圈に属し，婦人会・体育協会など

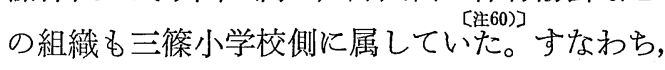
同校通学区域は都市化によって旧城下町地域と 一体化してもなお，旧町域と一致する社会領域 を維持していたといえよう。単なる行政区域境 界が通学区域境界として重視されないことは, 東浄 (17), 鈴が峰 (49) 両小学校ともに, 従来 の行政区域境界を全く無視した通学区域を有し ていることからも明らかである。

特異な例として, 日常生活の便が考慮されて 通学区域が变更され, さらに行政区域境界も変 更された場合がある。大芝 (38)・長束 (53: 祇 園町), 戸坂 (15)・原 (59: 祇園町) の各小学校 の例である。大芝小学校通学区域北端の地区は 元々祇園町に属し, 長束小学校の通学区域であ
61）市教委での聴き取りによる。
62）広島市立三篠小学校編『創立百周年記念誌・みささ』, 1974, による。
63） 1907年，三篠村は三篠町となる。
64）1882年, 牛田村は西隣の新山村を合併して牛田村と称した。1929年には広島市に合併し, 牛田町と改称している。
65）広島市立牛田小学校編『牛田小学校百年のあゆみ』, 1975, による。
66）もと向地地区と呼ばれた。現在の広島市西区大芝 $3 丁$ 目・大宮 3 丁目にあたる。 
った。ところが，太田川放水路の完成によって， この地区は長束小学校側の地区とは分離され, 大芝小学校への通学の核らが容易になった。そ こで，この地区の児童に区域外就学が認められ たが，住民は1972年に祇園町が広島市に合併す る時点で正式な通学区域変更を希望した。变更 は翌年に行われたが，この場合も，実際に社会 領域を構成していない行政区域は，通学区域設 定には意味をもたないことを示している。戸坂 小学校の例では, 戸坂町の一部が太田川をはさ んだ対岸にある祇園町に含まれ，正式には原小 学校の通学区域であった。しかしながら，原小 学校への通学はほとんど不可能であったため [注50),100 103頁]，この地区は早くから戸坂小学 校への区域外就学が認められていた。ここでも 1973年には正式に通学区域が変更された。

その他の例として，開発の新しい住宅団地は， 単独または複数の団地で児童数が 1 小学校を必 要とするようになるため，住宅団地が通学区域 の構成単位となっている。己斐東 (44)・山田 (45) ・ 鈴が峰 $(49) \cdot$ 東浄 (17) ・ 早稲田 (20) ・己 斐上の各小学校がその例である。

(3)新合併地域 新合併地域に拈ける小学校 通学区域は，明治初期～後期，明治後期～終戦, 終戦〜統廃合期，統廃合期〜現在の 4 時期を経 て形成されたと考兄られる。戦後の統廃合期は 1972年をもって終了したとみてよいであろゔ。 この地域には今な物旧来の地縁社会である大字 が残っている。それゆ光，小学校通学区域の形 成に大字の範囲や性格が深く関与してきたと考 它られる。
最初の明治初期〜後期の時期は，前述の 2 地 域と同様，教育制度自体の形成期である。まず， 学制によって小学区設定基準が人口 600 人以上 (注7)，43頁；注36)，527頁〕とされたのに応じ，通常 各村ごとに 1 ～小学校が設置された。現在の 高陽町・佐東町域では，すべての村に气れぞれ 1 小学校が設置された。当時，小学校が設置さ れなかったのは安佐町域の宮野村 (以下, 安佐町 大字宮野のよう飞記す), 可部町大字城 - 南原, 白木町大字古屋・有留・保垣であった。学区は, 一連の法令の改廃に応じて変わり, 小学校 令 （1886）では 1 郡区 1 学区制が採用された【注36), 1104頁」が，通学区域はほぼ村の範囲であったと みなしてよからら。

当時，頻繁に行われた小学校の設立・統廃合 は，就学率の向上に伴なら教室不足解消，おょ び教育財政の負担軽減が目的であったが，市制 ・町村制によって新町村が成立した頃の統合で は，別の目的も加わっていた。例它ば，現在の 沼田町域に和いて成立した戸山村では，合併前 の阿戸村・吉山村の旧村民意識が合併後も消兄 ず，1908年，両村の小学校を統合し，新しい村 としての一体感を得ようとした。これは, 当時 すでに，小学校が社会領域の中心とみなされる ようになっていた明らかな事例といえよう。

明治後期以降は，いくつかの統合や移転がみ られるものの, 各村にほぼ1 小学校が立地する 状態はほとんど恋わることなく終戦を迎える。

終戦〜統廃合期は，人口減少に伴なら小学校 の適正規模の維持，教育財政の負担軽減を目的 とする統廃合が相次いだ時期である。それゆえ，

67）市教委での聴き取りによる。

68）太田川の流路変化によるものと考えられているが，はっきりした原因は明らかでない。

69）広島市『広島市総合計画，実施計画書，昭和 47 年度～昭和 50 年度』，1972，82頁，によると，鈴が峰新住宅市街地開 発事業（全体計画，昭和39～50年度）に和いて，利便施設として教育施設 4 ケ所の設置が見込まれている。鈴が峰小学 校はそのうちの 1 つである。早稲田小学校もこれと同様な例である。

70) 1982年, 己斐小学校 (43) より分離独立。

71）例外として, 白木町の高南西小学校（後述）がある。

72）広島市編『沼田町史』，1980，548～551頁，および安古市町編『安古市町誌』１970，600頁，による。

73）前掲72）『沼田町史』，553頁，による。

74）前揭72）『沼田町史』，647一648頁，拉よび広島市編『白木町史』，1980，445頁，による。 
この時期は通学区域の拡大が目立った。新しい 通学区域は大字の範囲とされることが多く, 特 に大字域の広い安佐町・白木町に和いて明らか である。例觉ば，白木町では 3 つの統合が行わ れ，1959年統合の志屋小学校 (88) では 2 大字 (志路, 古屋), 1963年統合の三田小学校 (86) は 1 大字 (三田) が 新しい通学区域となった。こ れらの場合, 大字域が広く, 通学距離は延びた が，反対運動は起こらなかった。ここでは，統 合前の通学区域は児童の徒歩通学の便を重視し て設定されていたとみられ，その通学区域が必 ずしも社会領域と一致していたとは考完られな w。

しかしながら，このような大字を通学区域単 位とする統合は，その大字が一体的な交通圈を もつ 1 つの谷筋に存在する場合に限られるよう である。大字内に立地する集落が山陵によって 隔てられている場合, 大字は通学区域の単位と はならない。白木町に和いて，1977年に至って 廃校された高南西小学校が艺の良い例である。 同校の通学区域は大字市川の西端に位置する桧 山地区のみであった。市川の他の集落とは山陵 によって全く隔絶されて和り, 日常生活も西隣 の可部町大字大林と結びついていた。ぞのため, この地区は町境を越えた大林小学校 (84) の通 学区域に変更され，バス通学が行われるよらに なった。同様な例は可部町に扮いてもみられた。 第 8 図に示すように，大林 (84)・三大 (83) 両 小学校の通学区域は大字が地域単位となってい るが，それより西側の地区では，通学区域は大 字の区域とは関係なく設定されてきた。この地
区でも 1 大字内に立地する集落は山陵によって 隔てられている。もと川手小学校の通学区域の 場合, 学校統合の結果, 可部小学校 (81) の通 学区域として飛地状になった。炅れは，この地 区が渑山小学校 (79) には遠く：交つ交通機関 もないため，通学に国鉄可部線の利用できる可 部小学校を通学校とすることを住民が希望した からである。このように, 戦後学校統廃合を余 儀なくされた地区では, 通学区域の設定にあた って, 通学距離の増大や大字の範囲は必ずしも 問題とはされず，通学用の交通機関の有無が重 要な要因であった。

これらとは別の要因として，氏子圈が通学区 域設定に関与したかどうかを考えてみたい。第 8 図に示した亀北小学校の場合, 同校抢よび三 入小学校南原分校の通学区域は，その中間にあ る嶓崎神社を中心とする同一の氏子圈であった。 そのため; 両校統合の意見もあったが，両校の 通学区域境界が旧村境界であることが関係して， 亀北小学校は可部小学校 (81) 飞統合された。 結果的に氏子圈は通学区域の単位にならなかっ たとはいえ，通学区域の設定にあたり，明らか に一要因として考慮されている。しかしながら， 他の地区, 例えば前述の白木町の場合, 学校統 合以前の大字三田では小学校通学区域と氏子圈 が一致していたものの, 大字志路では両者は一 致していなかった。すなわち, 氏子圏は地縁社 会としてその範囲が通学区域設定にあたって考 慮されることはあっても，普遍的な要因ではな かったと考它られる。

上記の統廃合終了後, 現在に至る時期は, 広

75）現地での聴き取りによる。バス通学の不便はあっても, 複式授業で教育効率が落ちるよりも, 統合して設備を充実す るほうがよいと住民は考えたようである。

76）現地での聴き取りによる。

77）当時，すでに両町とも広島市に合併していた。

78）現地での聴き取りによる。

79）亀山村は大字綾ヶ谷・勝木・大毛寺・今井田・四日市からなり, 三入村は大字南原・上町屋・下町屋・桐原からなっ ていた。

80）現地での聴き取りによる。

81）大字三田のうち, 三田東小学校は上と中, 三田西小学校は下の地区を通学区域としていた。 


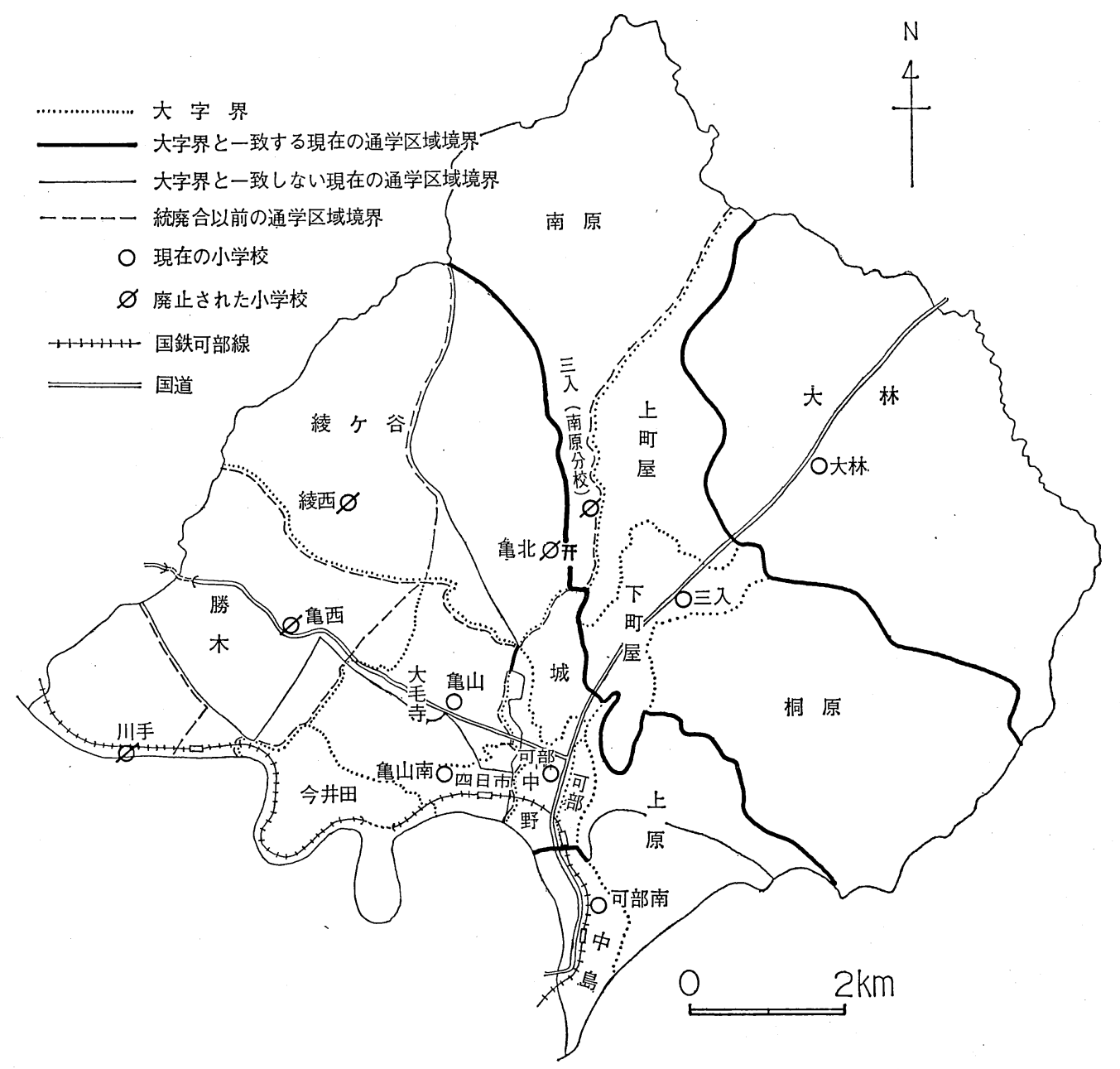

第 8 図 可部町に挌ける大字と通学区域

島市への合併条件の一つである小学校新設が多 くの町で行われ，通学区域が細分化された。こ の時期に招いて通学区域設定に関連する要因は, ぞの地区にも共通して，人口分布と通学時の交 通の安全性が最も重要である。スプロール的に 発展した祇園町や安古市町 (特に東部地区) では, 通学時の交通事故を避けるために，鉄道や国道 が通学区域境界とされる例が多い。通学時の交 通の安全性が重視されるのは, いわゆる校区紛 争がこの要因によって起こることが多い点から も明らかである。1981年に開校した佐東町の梅
林小学校の例でも, 新しく通学区域に指定され た地区の住民から，通学距離が長くなり，かつ 通学路の交通量が多くて危険であるという理由 で反対が起こった。この場合，同校が予定より 北に偏して建設されたにもかかわらず，予定ど 和りの通学区域設定が行われたことが紛争につ ながったと考兄られる。すなわち，通学時の交 通の安全性への配慮がいかに重要とはいえ，人 口増加の激しい地区では新設校建設用地の確保 が難しく，かつ学校規模も大きくなりがちであ るため，人口分布に基づいた小学校新設計画が

82）当時の合併建設計画書に小学校新設が揭げられていないのは，白木町，安佐町，沼田町である。

83） 1955年に安古市町が成立する以前の古市町の地区 (大字東野・中筋・古市), 特よび安村の一部 (大字中須・大町)。 
優先されて, 地域の実態に即した柔軟な対応が できないきらいがある。

これらの場合とは違って, 高陽ニュータウン に代表される計画的に造成された大規模住宅団 地では, 当初から小学校の設置と通学区域も定 められている[注32), 504, 507頁]。それゆ光, 人口 分布, 通学距離, 通学時の交通の安全性とい。 た通学区域設定に係わる要因は, 計画時にすで に考慮されているといえよう。また，この種の 団地では, その範囲に団地の名称をとり, 新た に大字として指定されている。可部町大字虹山， 安佐町大字あさひが丘・くすの木台, 高陽町大 字翠光台・城ケ丘がその例であり, 今後, 小学 校を中心として強固な社会領域化してゆくと考 えられる。これは, 前述した市街地周辺地域の 住宅団地でもいえることである。

\section{V むすび}

小学校通学区域は，義務教育制度が確立した 明治後期以降，一社会領域として地域に定着し てきた。その区域は基本的には人口分布に応じ て設定され，行政区域と同様に形式地域である。 しかし，通学区域設定にあたって，地域の実態 が考慮されてきたところから，区域設定時には すでに実質地域の様相を帯びていたといえる。 かかる小学校通学区域の形成過程について, 広 島市を事例として以上のように分析を行ってき た。通学区域形成に関与する要因は地域によっ て異なると考它られる。そこで，本論では事例 地域を性格の異なる 3 地域に分割し，それぞれ 時期区分を行ったらえで分析を進めた。すなわ ち, 旧城下町地域, 市街地周辺地域, 新合併地 域の各地域ごとに，小学校の立地掞よび通学区 域の変化とその要因を考察した。その結果，小 学校通学区域の形成過程は次の 4 地域類型に分 けて考えられ，それぞれに特徵的な関連要因の
あることが明らかになった。

まず，旧城下町地域では，城下町時代の町割 が小区 (大区小区制) の設定に影響したと考え られる。この各小区が学区 (学制) とされ, 現 在の通学区域の基礎が形成された。これらの各 小区は社会領域であったとはい方ず，後の小学 校増設に伴なら通学区域の設定も人口分布に基 ついて行われ，境界は明瞭な地物が採用される ことが多かった。しかし，その後戦災を受け， 区画整理が行われたことにより街区形態は一変 し，基本的には人口分布に応じながら，改めて 通学時の交通の安全性が考慮された通学区域に なった。

次に, 市街地周辺地域と新合併地域のうらス プロール的に発展した地域がある。この地域で は長く各村 1 小学校の状態が続き, 通学区域は 村域と一致した強固な社会領域をなしていた。 ところが，特に戦後の人口増加によって，この 地域は旧城下町地域と一体化した市街地に变貌 するに及び，旧村域は，ごく一部の地域を除い て通学区域としての意味をほとんど竦失した。 通学を含めた日常生活の便から, 市域変更に至 った例さえある。この地域に氺ける現在の通学 区域は，旧地域にかわる新しい社会領域といえ よう。そして，新たな通学区域設定にあたって は通学時の交通の安全性が最大の要因となって いる。しかし，また，この地域では人口増加に 対して小学校を新設しょうとしても, 用地の確 保が難しい。新設校が当初の計画とは異なる用 地に設置されてる，学校の適正規模の維持が優 先され, 計画ど和りの通学区域が設定されるこ とがあり，地域の実態に即した柔軟な対応がと りにくい。そのため，いわゆる校区紛争が起こ りやすいのもこの地域の特徵である。

これらの地域の周辺に位置する新合併地域の らち, 農村地域では通学区域の形成過程はこれ

84）安古市町の上安小学校 (62) 新設時にみられた校区紛争では, 度重なる通学区域変更によってコミュニティが破壤さ れるといら危惧も住民の間にあったようである。 
らの地域とはかなり異なっている。もとは各村 に $1 \sim 3$ 校の小学校が設置されたが, 戦後の人 口減少に伴ない，学校の適正規模の維持，教育 財政の負担軽減を目的とした統廃合が相次ぎ， 通学区域は拡大してきた。この地域では大字の 区域が重要な地縁社会とみなされるが，通学区 域は大字の範囲に関係なく設定されることが多 く，通学の便が第一義的に考慮されてきた。す なわち，大字が一体的な交通圈をもつ一つの谷 筋に位置する場合にのみ, 通学区域の単位とし て大字が用いられた。学校統合の際, 通学距離 の増大はさ注ど問題にされず，むしろバスや鉄 道など通学用の交通機関の有無が区域設定にあ たって最も重要な要因であった。

これらの 3 地域に対し, 新たに形成された地 域として，市街地周辺地域と新合併地域にある 大規模住宅団地の地域がある。ここでは団地造 成にあたって，小学校も計画的に設置されてい る。すなわち, 最初から人口分布，学校の適正 規模の維持, 通学距離, 通学時の交通の安全性 が考慮されて和り，他の公共施設も整備され， 通学区域はすでに設定時点で新しい社会領域の 形成が見込まれている。

以上，小学校通学区域の形成過程について整 理したが，通学区域設定にあたって終始関連し
てきたのは，当然のことながら人口分布である。 また，現在，4地域類型に共通する最も重要な 要因とい方るのは通学時の交通の安全性である。 地縁社会との関連では, 大字は通学区域設定に 係わってきたといえるが，氏子圈については， 通学区域設定時に考慮されることはあっても， すべての地域に共通する要因とは考它られなか った。このような過程を経て形成された小学校 通学区域は，地域類型別にみれば程度の差はめ るにせよ，その区域の住民が構成する社会領域 として大きな意味を持ち続けてきたとい方よう。 特に, 近隣集団がみられる以外に明瞭な地域単 位のない都心地域や市街地周辺のスプロール的 発展をみた地域では，小学校通学区域は今後さ らに重要な地域単位となってゆくであろう。

〔付記〕本稿は1981年度日本地理学会 - 人文地理 学会地理学合同大会での発表を骨子として加筆修正 したものである。本稿を作成するにあたり，終始ご 指導を頂いた森川洋先生, ならびに地理学教室の諸 先生方に心から感謝いたします。また，資料提供に 快く応じて下さり, 貴重な助言を頂いた広島県教育 振興会の笹村弘志氏，広島市立中央図書館長の信井 正行氏，広島市教育委員会の定岡野武夫 - 渡辺郁雄 の両氏をはじめ，現地で聴き取り調查に応じて下さ った方々に愿く扟礼申し上げます。

(広島大学総合科学部)

\title{
The Formation Process of Primary School Districts : A Case Study of Hiroshima City
}

\author{
Shigeru SAKAGAWA
}

School districts are one form of social region. The purpose of this study is to consider how primary school districts have been formed in relation to certain factors. It is assumed that the influence of those factors varies with the geographical characters of each region. Therefore, the author divided the case study area (Hiroshima City) into three regions: the region of the old castle town (inner city), the region surrounding the inner city, and the region which has been consolidated since 1971 . As a result of this analysis, the formation processes of primary school districts are 
classified into four types. These types are summarized as follows :

In the region of the old castle town (the inner city), it was decided at first that school districts would be the same as each Shoku established by the Daiku-Shoku-Sei. This area consisted of Buke-Yashiki (samurai districts), Machi-Yashiki (Chonin districts), and Shingai (newly opened districts). Though these blocks characterized each Shoku, they were not equivalent to social regions. Afterwards, a lot of primary schools were established. Those school districts were based on population distribution, and their boundaries were natural boundaries in many cases. However, the blocks of this area were changed by war damage and land readjustment after the war. Since then, school districts have been reformed according to the actual circumstances, especially in regard to traffic safety problems of school attendance.

There are sprawl areas in both the regions surrounding the inner city and the region which has been consolidated since 1971. In these areas, there had been one school in most of the villages for a long time. Therefore, each school district had been strongly united as the social region. After the war, the population increased and now these areas are contiguous with the inner city. The areas of original villages have lost their meaning as school districts. It is considered that the present school districts are the new social regions replacing the original villages. The traffic safety of school attendance has become the most important factor in the formation of school districts. On the other hand, there are few sites for new schools in these areas. It is difficult to establish new schools as previously planned. This is apt to cause social problems about school districts.

In the rural areas within the region, which have been consolidated since 1971, one to three schools were established in each village. However, the population decreased rapidly after the war and a lot of schools were combined. The aim of these school combinations was to maintain a reasonable scale for the schools and to reduce the costs of education. In these areas, school districts have been formed according to the convenience of school attendance. As a factor in the formation of school districts, the existence of transport facilities for school attendance is more important than the distance of school attendance. The Oaza, which is recognized as important territorial relational grouping, has been adopted as the unit of school districts in those cases where the Oaza is contained in one traffic region.

There are new towns in both the region surrounding the inner city and the region which has been consolidated since 1971. When these new towns are constructed, primary schools are established intentionally. The factors in the formation of school districts, for example, the population distribution, the distance of school attendance, the traffic safety of school attendance, etc., are considered in the new town planning. Therefore, school districts are expected to become the new social regions from their inception.

These results show us that the basic factor in the formation of school districts is the population distribution, and that the traffic safety of school attendance is the single most important and common factor at present. As regards territorial relational 
groupings, the Oaza has been important in the formation of school districts. Also Ujiko-ken (the territory of a tutelary deity) has been taken into consideration. However, it was found that Ujiko-ken was not a common factor in all areas. Primary school districts have been formed through these processes. Though there are some differences to a certain degree between areas, it is considered that primary school districts have been the important regional units as social regions. There was no evidence of a clear regional unit in the inner city and sprawl areas. Therefore, primary school districts are likely to become the more important regional units, especially in these areas. 